\title{
CHEMICAL COMPOSITION AND ANTIBACTERIAL AND ANTIOXIDANT ACTIVITIES OF THYMUS SATUREIOIDES COSS. ESSENTIAL OIL
}

\author{
HOUDA SBAYOU1 ${ }^{1}$, AWATIF BOUMAZA ${ }^{2}$, ABDERRAOUF HILALI' ${ }^{1}$, SOUAD AMGHAR ${ }^{*}$ \\ ${ }^{1}$ Laboratory of Agrofood and Health, Faculty of Sciences and Technologies, University Hassan 1st, Settat Km 3, B. P: 577, Morocco, ${ }^{2}$ Faculty \\ of Natural and Life Sciences and Earth and Universe Science, University of 8 May 1945. Guelma. Algeria, ${ }^{3}$ Laboratory of Improved Soil \\ Productivity and Environment. Mohammed V University Rabat, Higher Normal School, B. P.: 5118, Rabat, Morocco \\ Email: eamghar@gmail.com
}

Received: 28 Jun 2016 Revised and Accepted: 12 Aug 2016

\begin{abstract}
Objective: Thymus satureioides is a well-known aromatic perennial shrub widely used throughout the Mediterranean basin as a culinary herb, in traditional medicine for the treatment of a variety of diseases, and as a natural preservative ingredient in the food industry. The aim of this study was to analyze the chemical composition of T. Satureioides essential oil and to assess its antibacterial and antioxidant activities.
\end{abstract}

Methods: The chemical composition of the essential oil was investigated by Gas chromatography-mass spectrometry (GC-MS). The essential oil was evaluated for its antibacterial activity against Gram-positive and Gram-negative bacteria using agar diffusion method and macro-broth dilution. The antioxidant activity was tested by three different methods, namely DPPH free radical scavenging, $\beta$-carotene/linoleic acid and TBARS assays.

Results: Thirty compounds were identified, representing $85.52 \%$ of the total composition of this essential oil. Borneol (26.45\%) and thymol $(11.24 \%)$ were the major components. The oil had a bactericidal activity against all tested bacteria, with the exception of Pseudomonas aeruginosa. In addition, the T. satureioides essential oil revealed strong antioxidant activity in all conducted assays.

Conclusion: The findings suggest that essential oil of T. satureioides may be used as an alternative to synthetic antibiotics and antioxidants.

Keywords: Thymus satureioides, Chemical composition, Antibacterial activity, Antioxidant activity

(c) 2016 The Authors. Published by Innovare Academic Sciences Pvt Ltd. This is an open access article under the CC BY license (http://creativecommons. org/licenses/by/4. 0/) DOI: http://dx.doi.org/10.22159/ijpps.2016v8i10.13742

\section{INTRODUCTION}

Since their discovery, antibiotics have led to great advances in therapy and contributed to the development of modern medicine. The effectiveness of antibiotic therapy in controlling and limiting the spread of pathogens has raised hopes for eradicating all infectious diseases. Unfortunately, the emergence of antibiotic-resistant bacteria has decreased this wave of optimism. The rise of resistance is due to the immoderate and inappropriate use of antibiotics. Infections caused by resistant microorganisms often fail to respond to the conventional treatment, engendering prolonged illness, a rise in health care costs, and increased risk of death [1].

The oxidation process is one of the most important routes for producing free radicals in food, drugs and even living systems. Lipid peroxidation in fats and fatty foods deteriorates their quality, causes chemical spoilage, and generates free radicals and reactive oxygen species. Free radicals can damage cells, and may play a role in heart disease, cancer and other diseases [2]. Synthetic antioxidants, such as butylated hydroxyl anisole (BHA), butylated hydroxyl toluene (BHT), and tertbutyl hydroquinone (TBHQ), are suspected to cause negative health effects [3]. Thus, more attention has been focused recently on the development of natural, safe and efficient antioxidant compounds. The plant kingdom is a rich source of a wide range of natural products. About three-quarter of the world's population relies on plants and plant extracts for their healthcare [4].

Thymus species are aromatic plants of the Mediterranean flora with a wide range of biological properties that are commonly used as spices and as traditional medicine remedies [5-7]. Several studies have shown that they have strong antibacterial, antifungal, antiviral, and antioxidant activities [5, 8, 9]. Within the Thymus genus, Thymus satureioides is a North African species typical of arid habitats, which is used in Moroccan folk medicine to treat whooping cough, bronchitis, and rheumatism [10]. T. satureioides has been reported to possess several medicinal properties including analgesic [6], microbiocidal [11, 12], larvicidal [12], hypolipidemic and antioxidant activities [14]. These properties have been attributed to the essential oil (EO) contained in the species, as well as the presence of non-volatile compounds including polyphenols and flavonoids [15].

The aim of this study was to determine the chemical composition of the essential oil of T. satureioides and to investigate its antibacterial and antioxidant activities.

\section{MATERIALS AND METHODS}

\section{Essential oil}

The Thymus satureioides was collected from Taroudant (South of Morocco, its geographical coordinates are $30^{\circ} 28^{\prime} 48^{\prime \prime}$ North, $8^{\circ} 51^{\prime} 36^{\prime \prime}$ West) during April-July 2009. The essential oil was produced by Santis Company using steam distillation from the leaves and stems of Thymus satureioides.

\section{Chemicals and reagents}

Methanol, $\beta$-carotene, chloroform, linoleic acid, Tween 40, potassium chloride, Trichloroacétique acid (TCA), n-butanol, BHT (Butylated hydroxytoluene) and DPPH (2,2-diphenyl-1-picrylhydrazyl) were purchased from Sigma-Aldrich, Germany. Ascorbic acid and thiobarbituric acid were obtained from Merck, Germany. All chemicals used were of analytical grade.

\section{Gas chromatography-mass spectrometry}

Gas chromatography-mass spectrometry analyses were performed with a gas chromatograph (Trace GC Ultra) coupled to a mass spectrometer (Polaris Q ion trap MS). The column used was a VB-5 capillary column (Methylpolysiloxane with $5 \%$ phenyl; $30 \mathrm{~m} \times 0.25$ $\mathrm{mm} \times 0.25 \mu \mathrm{m}$ film thickness).

The column temperature was initially kept at $40{ }^{\circ} \mathrm{C}$ for 2 min, then gradually increased to $180^{\circ} \mathrm{C}$ at a rate of $4{ }^{\circ} \mathrm{C} / \mathrm{min}$ and finally raised to $300{ }^{\circ} \mathrm{C}$ for $2 \mathrm{~min}$ at $20{ }^{\circ} \mathrm{C} / \mathrm{min}$. Fragmentation was performed by electron impact at $70 \mathrm{eV}$. The injection volume was $1 \mu \mathrm{l}$. Samples were injected in the split mode using helium as a carrier gas $(1.4 \mathrm{ml} / \mathrm{min})$. 


\section{Antibacterial activity}

\section{Bacterial strains}

The essential oil was tested against eight bacteria. Three standard strains: Escherichia coli (ATCC 25922), Staphylococcus aureus (ATCC 29213), Pseudomonas aeruginosa (ATCC 27853) (Microbiology Laboratory, Faculty of Pharmacy, University of Barcelona, Spain) and five clinically isolated strains: Escherichia coli, Staphylococcus aureus, Pseudomonas aeruginosa, Enterobacter cloacae, Enterococcus faecium (Microbiology Laboratory, CHU Ibn Rochd, Casablanca, Morocco).

\section{Antibacterial screening}

The agar diffusion method was used for the determination of antibacterial activity of essential oil [16]. Filter paper discs $(6 \mathrm{~mm}$ in diameter) were impregnated with $10 \mu \mathrm{l}$ of essential oil and transferred into the Luria-Bertani Agar present in Petri dishes which had been previously seeded by spreading $1 \mathrm{ml}$ of bacterial suspension adjusted to $10^{6} \mathrm{CFU} / \mathrm{ml}$. The Petri dishes were incubated at $37{ }^{\circ} \mathrm{C}$ for $24 \mathrm{~h}$. The diameter of inhibition zones was measured in millimeters. Amoxicillin (25 $\mu \mathrm{g} /$ disc) was used as a standard antibacterial drug. All tests were performed in triplicate.

\section{Determination of the minimum inhibitory concentration (MIC) and minimum bactericidal concentration (MBC)}

The broth macrodilution method was employed to determine the minimum inhibitory concentration (MIC) [17]. Serial dilutions of essential oil ranging from $20 \mu \mathrm{l} / \mathrm{ml}$ to $0.15 \mu \mathrm{l} / \mathrm{ml}$ were prepared in test tubes containing Luria-Bertani Broth with $0.15 \%$ agar. Each tube was inoculated with a bacterial suspension adjusted to $10^{6}$ $\mathrm{CFU} / \mathrm{ml}$. Controls containing medium with either microorganisms or the essential oil alone were included. The tubes were then incubated at $37{ }^{\circ} \mathrm{C}$ for $24 \mathrm{~h}$. MIC values were defined as the lowest concentrations of essential oil at which the absence of growth was recorded. To determine the minimum bactericidal concentration (MBC), $10 \mu \mathrm{l}$ from tubes in which bacterial growth was not observed, was spread on Muller Hinton Agar and incubated at $37^{\circ} \mathrm{C}$ for $24 \mathrm{~h}$. The MBC was defined as the lowest concentration of essential oil at which the incubated microorganism was completely killed. Each test was performed in triplicate.

\section{Antioxidant activity}

\section{DPPH free radical scavenging activity}

The hydrogen atom or electron donation abilities of the essential oil were measured from the bleaching of the purple-coloured methanol solution of 2,2-diphenyl-1-picrylhydrazyl (DPPH). This spectrophotometric assay uses the stable radical DPPH as a reagent [18]. $100 \mu \mathrm{l}$ of each concentration of essential oil was mixed with $1.3 \mathrm{ml}$ of DPPH methanol solution (0.004\%). After incubation in darkness at ambient temperature, the absorbance was measured at $517 \mathrm{~nm}$ using a spectrophotometer (Shimadzu UV-1800). Ascorbic acid was used as a positive control and methanol as a negative control. All analyses were carried out in triplicate. The percent inhibition of the DPPH radical was calculated according to the formula:

$$
\% \text { Inhibition }=\left(\frac{\mathrm{Ab}-\mathrm{Aa}}{\mathrm{Ab}}\right) \times 100
$$

Where $\mathrm{Ab}$ is the absorbance of the blank sample and $A a$ is the absorbance of the essential oil. The sample concentration providing $50 \%$ inhibition $\left(\mathrm{IC}_{50}\right)$ was calculated by plotting inhibition percentages against the concentration of the sample.

\section{$\beta$-carotene/linoleic acid assay}

The $\beta$-carotene/linoleic acid test evaluates the ability of a product to inhibit the formation of conjugated diene hydroperoxides resulting from oxidation of linoleic acid [19]. A mixture of $\beta$-carotene and linoleic acid was prepared by adding $0.5 \mathrm{mg} \beta$-carotene to $1 \mathrm{ml}$ chloroform, $25 \mu \mathrm{l}$ linoleic acids, and $200 \mathrm{mg}$ Tween 40. The chloroform was then completely evaporated, and $100 \mathrm{ml}$ of oxygenated distilled water was added to the mixture with vigorous stirring. $350 \mu \mathrm{l}$ of various concentrations of essential oil were added to $2.5 \mathrm{ml}$ of the above emulsion in test tubes. BHT was used as a positive control and methanol as a negative control. The absorbance values were measured at $490 \mathrm{~nm}$ after $1 \mathrm{~h}, 2 \mathrm{~h}, 3 \mathrm{~h}, 4 \mathrm{~h}, 6 \mathrm{~h}, 24 \mathrm{~h}$ and $48 \mathrm{~h}$ of incubation at ambient temperature. Antioxidant activity (AA) was calculated using the formula:

$$
\mathrm{AA} \%=(\mathrm{Ae} / \mathrm{Ac}) \times 100
$$

Where Ae is the absorbance in the presence of essential oil and Ac is the absorbance in the presence of BHT (positive control). All tests were carried out in triplicate.

\section{TBARS assay}

The TBARS assay quantifies oxidative stress by measuring the peroxidative damage to lipids that occurs with free radical generation. Free radical damage to lipids results in the production of malondialdehyde (MDA) which reacts with thiobarbituric acid (TBA) under conditions of high temperature and acidity generating a chromogen that can be used to quantify oxidative damage (lipid peroxidation) [20].

The assay was carried out according to the method reported by [21]. The egg yolk (10\%, v/v) solution was prepared in $\mathrm{KCl}(1.15 \%, \mathrm{w} / \mathrm{v})$. It was homogenized for $30 \mathrm{sec}$ and ultrasonicated for $5 \mathrm{~min} .500 \mu \mathrm{l}$ of the homogenate was added to $100 \mu \mathrm{l}$ of essential oil dissolved in methanol, and the volume was brought up to $1 \mathrm{ml}$ with distilled water. $0.5 \mathrm{ml}$ of this mixture was added to $0.5 \mathrm{ml}$ of trichloroacetic acid $(20 \%, v / v)$ and $1 \mathrm{ml}$ of TBA $(0.67 \%)$. Samples were vortexed and left in a $100{ }^{\circ} \mathrm{C}$ water bath for $15 \mathrm{~min}$. When they had cooled, 4 $\mathrm{ml}$ of n-butanol was added. After centrifugation at $3000 \mathrm{rpm}$ for 15 $\mathrm{min}$, the absorbance was measured at $530 \mathrm{~nm}$. Antioxidant Index percentage (AI \%) was calculated using the following formula:

$$
\mathrm{AI} \%=(\mathrm{A} 0-\mathrm{A} 1 / \mathrm{A} 0) \times 100
$$

Where $\mathrm{A} 0$ is the absorbance of the completely oxidized sample and A1 is the absorbance of the test sample.

\section{Statistical analysis}

The antioxidant and antibacterial results are stated in mean \pm standard deviation. Analysis of variance was performed by ANOVA procedures (SPSS 20.0 for Windows). Significant differences between means were determined by Tukey post hoc tests. Differences at $\mathrm{P}<0.05$ were considered statistically significant.

\section{RESULTS AND DISCUSSION}

\section{Chemical composition}

As shown in table 1, thirty compounds were identified, representing $85.52 \%$ of the total composition of Thymus satureioides essential oil. The predominant components were borneol $(26.45 \%)$ and thymol (11.24\%).

These results are in accordance with those reported by [22] for the T. satureioides growing in the Agoundis Valley (Morocco) in which the borneol content ranged between 22.67 and 37.47\%. Other studies have shown the presence of different volatile constituents in some Moroccan T. satureioides populations. Lattaoui et al. [11] reported the major compounds to be borneol (31.2\%), camphene (27.4\%), $\alpha$-pinene (17.5\%) and linalool (6.3\%). Jaafari et al. [23] and El Bouzidi et al. [24] have shown the codominance of borneol (21.1$30.03 \%)$ and carvacrol (26.5-35.9\%)

The intraspecific chemical variability of Moroccan T. satureioides can be attributed to the environmental conditions [25]. In fact, Kasrati et al. [26] compared the oil composition obtained from the three $T$. satureioides populations from Morocco and showed that the oil obtained from Er-Rich populations was characterized by carvacrol (45.3\%), p-cymene (8.9\%), linalool (8.4\%), borneol (7.5\%), (E)caryophyllene $(6.4 \%)$ and $\gamma$-terpinene $(6.3 \%)$ as the main compounds. The oil obtained from the Taws population was characterized by carvacrol $(25.3 \%)$, borneol $(19.7 \%)$, camphene (7.6\%), p-cymene (6.6\%), (E)-caryophyllene $(5.4 \%)$ and $\gamma$-terpinene $(5.0 \%)$ as the major constituents; whereas, the population from Ourika was composed of carvacrol (26.5\%), borneol (20.1\%), 
camphene (8.0\%), (E)-caryophyllene (5.7\%), $\gamma$-terpinene (5.6\%), pcymene (5.4\%) and linalool (3.8\%).

\section{Antibacterial activity}

The antimicrobial activity of $T$. satureioides essential oil against eight species of microorganisms was assessed by evaluating the diameter of the inhibition zones and the determination of MIC and MBC values, as shown in table 2 .
T. saturejoides essential oil inhibited growth of all the tested microorganisms, including the clinically-derived strains, except $P$ s. aeruginosa. This Gram-negative bacterium is notorious for its resistance to antibiotics and involvement in nosocomial infections.

This resistance appears to be related to the nature of the outer membrane, which is composed of lipopolysaccharides that form an impermeable barrier to hydrophobic compounds [27].

Table 1: Chemical composition of Thymus satureioides essential oil by GC-MS

\begin{tabular}{|c|c|c|c|}
\hline & Component & Retention time & Area (\%) \\
\hline 1 & $\alpha$-Pinene & 7.39 & 0.35 \\
\hline 2 & $\alpha$-Phellandrene & 7.62 & 0.29 \\
\hline 3 & Camphene & 8.25 & 7.16 \\
\hline 4 & 3-Carene & 9.20 & 0.68 \\
\hline 5 & $\alpha$-Terpinene & 10.68 & 0.39 \\
\hline 6 & $\beta$-Cymene & 10.94 & 2.18 \\
\hline 7 & Alloocimene & 11.11 & 1.56 \\
\hline 8 & Santolina triene & 13.72 & 1.93 \\
\hline 9 & $\alpha$-Campholene aldehyde & 15.07 & 0.70 \\
\hline 10 & Borneol & 15.97 & 26.45 \\
\hline 11 & 4-Terpineol & 16.35 & 1.35 \\
\hline 12 & $\alpha$-Terpinyl acetate & 16.86 & 10.99 \\
\hline 13 & Isobornyl formate & 18.07 & 0.53 \\
\hline 14 & 2-Isopropyl-4-methylanisole & 18.72 & 1.51 \\
\hline 15 & Isobornyl acetate & 20.08 & 1.87 \\
\hline 16 & 5-Isopropyl-2-methylphenol & 20.50 & 0.76 \\
\hline 17 & Thymol & 20.75 & 11.24 \\
\hline 18 & $\alpha$-Copaene & 23.04 & 0.37 \\
\hline 19 & Hexahydroindan & 23.31 & 0.11 \\
\hline 20 & Guaia-3,9-diene & 24.10 & 0.24 \\
\hline 21 & $\beta$-Caryophyllene & 24.39 & 8.27 \\
\hline 22 & Calarene & 24.69 & 0.17 \\
\hline 23 & $\alpha$-Guajene & 25.42 & 0.37 \\
\hline 24 & $\alpha$-Ferulene & 25.65 & 0.32 \\
\hline 25 & Ledene & 26.49 & 0.11 \\
\hline 26 & Valencene & 26.72 & 0.16 \\
\hline 27 & $\alpha$-Muurolene & 26.89 & 0.25 \\
\hline 28 & $\gamma$-Cadinene & 27.28 & 0.79 \\
\hline 29 & Caryophyllene oxide & 29.23 & 0.50 \\
\hline 30 & Pentasiloxane, dodecamethyl- & 43.62 & 3.92 \\
\hline
\end{tabular}

Table 2: Antibacterial activity of $T$. satureioides essential oil

\begin{tabular}{|c|c|c|c|c|}
\hline \multirow[t]{2}{*}{ Tested microorganisms } & \multicolumn{2}{|c|}{ Inhibition zone diameter (mm) } & \multirow[t]{2}{*}{$\mathrm{MIC}(\mu \mathrm{l} / \mathrm{ml})$} & \multirow[t]{2}{*}{$\operatorname{MBC}(\mu \mathrm{l} / \mathrm{ml})$} \\
\hline & Essential oil & Antibiotic control & & \\
\hline \multicolumn{5}{|l|}{ Gram-negative bacteria } \\
\hline E. coli ATCC 25922 & $15 \pm 0$ & $25 \pm 0$ & 0.625 & 0.625 \\
\hline E. coli & $21 \pm 0$ & $0 \pm 0$ & 1.25 & 1.25 \\
\hline Ps. aeruginosa ATCC 27853 & $0 \pm 0$ & $0 \pm 0$ & $>20$ & $>20$ \\
\hline Ps. aeruginosa & $0 \pm 0$ & $0 \pm 0$ & $>20$ & $>20$ \\
\hline Enterobacter cloacae & $15.5 \pm 0.7$ & $12 \pm 0$ & 0.625 & 0.625 \\
\hline \multicolumn{5}{|l|}{ Gram-positive bacteria } \\
\hline Staph. aureus ATCC 29213 & $23 \pm 0$ & $16 \pm 0$ & 0.312 & 0.312 \\
\hline Staph. aureus & $15 \pm 0$ & $12 \pm 0$ & 0.625 & 0.625 \\
\hline Enterococcus faecium & $16 \pm 0$ & $18 \pm 0$ & 1.25 & 1.25 \\
\hline
\end{tabular}

Values represent mean \pm standard deviation of three replicates.

According to the disc diffusion results, the inhibition zones of bacteria ranged from $0 \pm 0$ to $23 \pm 0 \mathrm{~mm}$ (table 2). The MBC values were equivalent to the MIC values, confirming the bactericidal effect of the essential oil tested. Staph. aureus ATCC 29213 was the most sensitive strain with MIC $=\mathrm{MBC}=0.312 \mu \mathrm{l} / \mathrm{ml}$.

The bactericidal activity of $T$. satureioides essential oil may be attributed to the presence of high concentrations of borneol and thymol. Thymol is an oxygenated monoterpene well known with its antimicrobial potential $[28,29]$ which results from its ability to induce structural and functional alterations in the cytoplasmic membrane [30]. In fact, thymol affects membrane permeability and results in the release of $\mathrm{K}^{+}$ions and ATP [31-33]. It can also interact with membrane proteins and intracellular targets.

However, it is difficult to attribute the antimicrobial activity of essential oil, characterized by a complex mixture, to a single or particular constituent. In fact, some studies have shown that the antibacterial activity of whole essential oils is greater than that of the sum of their individual components [34]. Therefore, synergistic and antagonistic effects between several components in the oil are possible, and may contribute to the overall antibacterial activity of these oils. 


\section{Antioxidant activity}

The antioxidant activity of essential oil of T. satureioides was determined by three different test systems-namely the DPPH, $\beta$ carotene/linoleic acid, and TBARS assays. The reduction ability of DPPH radicals formation was determined by the decrease in its absorbance at $517 \mathrm{~nm}$ induced by antioxidants. The scavenging ability of $T$. satureioides essential oil increased with increasing oil concentrations. As demonstrated in table 3 , the oil showed high scavenging value $\left(\mathrm{IC}_{50}=0.25 \pm 0.03 \mathrm{mg} / \mathrm{ml}\right)$. There was no statistically significant difference $(p>0.05)$ between EO and ascorbic acid (positive control).

Table 3: Antioxidant activity of $T$. satureioides essential oil, as measured by the DPPH, $\beta$-carotene/linoleic acid, and TBARS tests

\begin{tabular}{|c|c|c|c|}
\hline Antioxidant tests & Essential oil & Ascorbic acid & BHT \\
\hline DPPH assay $\left(\mathrm{IC}_{50} \mathrm{mg} / \mathrm{ml}\right)$ & $0.25 \pm 0.03 a$ & $0.14 \pm 0.001 \mathrm{a}$ & - \\
\hline$\beta$-carotene/linoleic acid assay (I\%) & $81.78 \pm 0.37 \mathrm{a}$ & - & $98.13 \pm 0.94 b$ \\
\hline TBARS assay $\left(\mathrm{I}_{50} \mathrm{mg} / \mathrm{ml}\right)$ & $300.32 \pm 1.50$ & - & - \\
\hline
\end{tabular}

Values represent mean \pm standard deviation of three replicates. For each test, values followed by the same letter are not significantly different (p>0.05).

In the $\beta$-carotene/linoleic acid test, $\beta$-carotene undergoes rapid discoloration in the absence of an antioxidant. This is because of the coupled oxidation of $\beta$-carotene and linoleic acid, which generates free radicals. The EO exhibited high antioxidant activity, with $\mathrm{I} \%=$ $81.78 \pm 0.37 \%$, but this was still lower than that of the synthetic antioxidant BHT (I\% = 98.13 $\pm 0.94 \%)$ (table 3).

The thiobarbituric acid-reactive substances (TBARS) assay spectrophotometrically measures, at $532 \mathrm{~nm}$, the pink pigment produced by the reaction of thiobarbituric acid (TBA) with malonaldehyde (MDA), a secondary lipid peroxidation product. The antioxidant activity of $T$. satureioides essential oil was dosedependent. The highest activity ( $\mathrm{I}_{50}$ value of $300.32 \pm 1.50 \mathrm{mg} / \mathrm{ml}$ ) was observed at high EO concentrations. However, in other studies, Thyme EO exhibited stronger antioxidant activity in the TBARS assay, with an $\mathrm{IC}_{50}$ value of $0.004 \mu \mathrm{g} / \mathrm{ml}$ for $T$. serphyllum and 0.31 $\mu \mathrm{g} / \mathrm{ml}$ for T. algeriensis [35].

EOs are complex mixtures of several classes of compounds, and this complexity often makes it difficult to explain the activity pattern. The antioxidant activity of $T$. satureioides EO could be attributed to the presence of thymol. In fact, the in vitro antioxidant activity of the essential oils of several Thymus species has been reported previously [36,37], and this activity has been attributed mainly to their content of phenolic components, especially thymol and carvacrol [38], which are capable of donating hydrogen atoms to inhibit lipid peroxidation [39]. The presence and the number of free hydroxyl groups are key determinants of the antioxidant activity of phenols [40]. Beside their antiradical activities [41], thymol and carvacrol express a strong antioxidant action, similar to that of $\alpha$ tocopherol, which is used as a reference antioxidant in lipid systems [37]. Other constituents of the T. satureioides essential oil, such as borneol could also be taken into account for their possible synergistic or antagonistic effects.

\section{CONCLUSION}

The results obtained in this study confirm the antibacterial and antioxidant activities of $T$. satureioides essential oil. The essential oil tested represents a natural source of bioactive compounds. Thus, this study suggests that $T$. satureioides essential oil may be used to prevent the growth of bacteria and to replace synthetic preservatives. However, further research is needed to evaluate the safety and the effectiveness of this EO in food systems.

\section{ACKNOWLEDGMENT}

The authors would like to thank Santis Company, Prof. Ababou, Prof. Boukachabine (Faculty of Sciences and Technologies, Settat) and Prof. Zerouali (CHU Ibn Rochd) for their kind collaborations. Special thanks also go to Prof. Manresa (Faculty of Pharmacy, Barcelona) for providing standard strains.

\section{CONFLICTS OF INTERESTS}

\section{Declared none}

\section{REFERENCES}

1. Bisht R, Katiyar A, Singh R, Mittal P. Antibiotic resistance-a global issue of concern. Asian J Pharm Clin Res 2009;2:34-9.
2. Lobo V, Patil A, Phatak A, Chandra N. Free radicals, antioxidants and functional foods: Impact on human health. Pharmacogn Rev 2010;4:118-26.

3. Sannigrahi S, Mazumder UK, Pal DK, Parida S. In vitro antioxidant activity of methanol extract of Clerodendrum fortunatum Linn. Orient Pharm Exp Med 2009;9:128-34.

4. Farhan H, Rammal H, Hijazi A, Hamad H, Daher A, Reda M, et al. In vitro antioxidant activity of ethanolic acid and aqueous extracts from crude Malva Parviflora L. grown in Lebanon. Asian J Pharm Clin Res 2012;5 Suppl 3:234-8.

5. Ismaili H, Milella L, Fkih-Tetouani S, Ilidrissi A, Camporese A Sosa $\mathrm{S}$, et al. In vivo topical anti-inflammatory and in vitro antioxidant activities of two extracts of Thymus satureioides leaves. J Ethnopharmacol 2004;91:31-6.

6. Elhabazi K, Ouacherif A, Laroubi A, Aboufatima R, Abbad A, Benharref A, et al. the Analgesic activity of three thyme species Thymus satureioides, Thymus Moroccans and Thymus leptobotrys. Afr J Microbiol Res 2008;2:262-7.

7. Vermaa RS, Padaliaa RC, Chanotiyab CS, Chauhana A. Chemical investigation of the essential oil of Thymus linearis (Benth. ex Benth) from western Himalaya India. Nat Prod Res 2010;24:1890-6.

8. Dandlen SA, Lima AS, Mendes MD, Miguel MG, Faleiro ML, Sousa MJ, et al. Antioxidant activity of six portuguese thyme species essential oils. Flavour Fragrance J 2010;25:150-5.

9. Saad A, Fadli M, Bouaziz M, Benharref A, Mezrioui NE, Hassani L. Anticandidal activity of the essential oil of Thymus maroccanus and Thymus broussonetii and their synergism with amphotericin B and fluconazole. Phytomed 2010;17:1057-60.

10. Bellakhdar J. Medicinal plants in North Africa and basic care, Handbook of modern herbal medicine, Le Fennec, Casablanca; 2006.

11. Lattaoui N, Tantaoui-Elaraki A, Errifi A. Composition and antimicrobial activity of the essential oils of Thymus broussonetii, T. zygis and T. saturejoides. J Essent Oil Res 1993;5:45-53.

12. Mayaud L, Carricajo A, Zhiri A, Aubert G. Comparison of bacteriostatic and bactericidal activity of 13 essential oils against strains with varying sensitivity to antibiotics. Lett Appl Microbiol 2008;47:167-73.

13. Pavela R. Larvicidal property of essential oils against Culex quinquefasciatus Say (Diptera: Culicidae). Ind Crops Prod 2009;30:311-5.

14. Ramchoun M, Harnafi H, Alem C, Büchele B, Simmet T, Rouis M, et al. Hypolipidemic and antioxidant effect of polyphenol-rich extract from Moroccan thyme varieties. E-SPEN J 2012;7:119-24.

15. Boros B, Jakabov S, Dörnyei A, Horváth G, Pluhár Z, Kilár F, et al. Determination of polyphenolic compounds by liquid chromatography-mass spectrometry in Thymus species. Chromatogr A 2010;1217:7972-80.

16. National Committee for Clinical Laboratory Standards (NCCLS). Performance standards for antimicrobial disk susceptibility test, 6th ed. Approved Standard. M2-A6. Wayne, Delaware County, PA; 1997.

17. Bouhdid S. Antimicrobial and antioxidant activities of essential oils. Doctoral Thesis. Univesity Abdelmalek Essadi, Faculty of Science. Tetouan; 2009 
18. Burits M, Bucar F. Antioxidant activity of Nigella sativa essential oil. Phytother Res 2000;14:323-8.

19. Aslan A, Güllüce M, Sökmen M, Adigüzel A, Sahin F, Özkan H. Antioxidant and antimicrobial properties of lichens Cladonia foliacea, Dermatocarpon miniatum, Everinia divaricata, Everinia prunastri and Neofuscella pulla. Pharm Biol 2006;44:247-52.

20. Oakes KD, Van Der Kraak GJ. The utility of the TBARS assay in detecting oxidative stress in white sucker (Catostomus commersoni) populations exposed to pulp mill effluent. Aquat Toxicol 2003;63:447-63.

21. Okhawa H, Ohishi N, Yagi K. Assay of lipid peroxides in animal tissue by the thiobarbituric reaction. Anal Biochem 1979; $95: 351-8$

22. Zenasni L, Bakhy K, Gaboun F, Mousadak R, Benjouad A, Al Faiz C. Essential oil composition, and biomass productivity of Moroccan endemic Thymus satureioides Coss. and Ball. growing in the agoundis valley. J Med Plants Res 2014;8:504-12.

23. Jaafari A, Ait Mouse H, Rakib EM, Ait M'barek L, Tilaoui T, Benbakhta C, et al. Chemical composition and antitumor activity of different wild varieties of Moroccan thyme. Braz J Pharmacog 2007;17:477-91.

24. El Bouzidi L, Alaoui Jamali C, Bekkouche K, Hassani L, Wohlmuth $\mathrm{H}$, Leach D, et al. Chemical composition, antioxidant and antimicrobial activities of essential oils obtained from wild and cultivated Moroccan Thymus species. Ind Crops Prod 2013;43:450-6.

25. De Lisi A, Tedone L, Montesano V, Sarli G, Negro D. Chemical characterization of Thymus populations belonging from Southern Italy. Food Chem 2011;125:1284-6.

26. Kasrati A, Alaoui Jamali C, Fadli M, Bekkouche K, Hassani L, Wohlmuth $\mathrm{H}$, et al. Antioxidative activity and synergistic effect of Thymus satureioides Coss. essential oils with cefixime against selected foodborne bacteria. Ind Crops Prod 2014;61:338-44.

27. Mann CM, Cox SD, Markham JL. The outer membrane of Pseudomonas aeruginosa NCTC 6749 contributes to its tolerance to the essential oil of Melaleuca alternifolia (Tea tree oil). Lett Appl Microbiol 2000;30:294-7.

28. Castilho PC, Savluchinske-Feio S, Weinhold TS, Gouveia SC. Evaluation of the antimicrobial and antioxidant activities of essential oils, extracts and their main components from oregano from Madeira Island, Portugal. Food Control 2012;23:552-8.

29. Kurdelas RR, López S, Lima Feresin GE, Zygadl J, Zacchino S, López ML, et al. Chemical composition, anti-insect and antimicrobial activity of Baccharis darwinii essential oil from Argentina, Patagonia. Ind Crops Prod 2012;40:261-7.

30. Sikkema J, De Bont JAM, Poolman B. Mechanisms of membrane toxicity of hydrocarbons. Microbiol Rev 1995;59:201-22.
31. Walsh SE, Maillard JY, Russell AD, Catrenich CE, Charbonneau DL, Bartolo RG. Activity and mechanisms of action of selected biocidal agents on Gram-positive and negative bacteria. J Appl Microbiol 2003;94:240-7.

32. Xu J, Zhou F, Ji BP, Pei RS, Xu N. The antibacterial mechanism of carvacrol and thymol against Escherichia coli. Lett Appl Microbiol 2008;47:174-9.

33. Lambert RJW, Skandamis PN, Coote PJ, Nychas GJE. A study of the minimum inhibitory concentration and mode of action of oregano essential oil, thymol and carvacrol. J Appl Microbiol 2001;91:453-62.

34. Gill AO, Delaquis P, Russo P, Holley RA. Evaluation of antilisterial action of cilantro oil on vacuum packed ham. Int J Food Microbiol 2002;73:83-92.

35. Nikolić M, Glamočlija J, Ferreira ICFR, Calhelha RC, Fernandes A, Marković T, et al. Chemical composition, antimicrobial, antioxidant and antitumor activity of Thymus serpyllum $L$, Thymus Algerians is boiss. and reut and thymus vulgaris $L$. essential oils. Ind Crops Prod 2014;52:183-90.

36. Tepe B, Sokmen M, Akpulat HA, Daferera D, Polissiou M, Sokmen A. Antioxidative activity of the essential oils of Thymus sipyleus subsp. sipyleus var. sipyleus and Thymus sipyleus subsp. sipyleus var. rosulans. J Food Eng 2005;66:447-54.

37. Bounatirou S, Smiti S, Miguel MG, Faleiro L, Rejeb MN, Neffati $\mathrm{M}$, et al. Chemical composition, antioxidant and antibacterial activities of the essential oils isolated from Tunisian Thymus capitatus. Food Chem 2007;105:146-55.

38. Ruberto G, Baratta MT. Antioxidant activity of selected essential oil components in two lipid model systems. Food Chem 2000;69:167-74.

39. Amić D, Davidović-Amić D, Bešlo D, Trinajstić N. Structureradical scavenging activity relationship of flavonoids. Crotica Chem Acta 2003;76:55-61.

40. Sharififar F, Dehghan-Nudeh G, Mirtajaldini M. Major flavonoids with antioxidant activity from Teucrium polium L. Food Chem 2008;112:885-8.

41. Avlessi F, Dangou J, Wotto VD, Alitonou GA, Sohounhloue DK, Menut C. Antioxidant properties of Clausena anisata (Wild) Hook leaves essential oil. C R Chim 2004;7:1057-61.

\section{How to cite this article}

- Houda Sbayou, Awatif Boumaza, Abderraouf Hilali, Souad Amghar. Chemical composition and antibacterial and antioxidant activities of Thymus satureioides coss. essential oil. Int J Pharm Pharm Sci 2016;8(10):183-187. 